\title{
An Introduction to Managing Medullary Thyroid Cancer
}

\author{
Jan Willem de Groot', Thera P. Links', Robert M.W. Hofstra ${ }^{3}$, John T.M. Plukker ${ }^{4}$ \\ Department of Internal Medicine, Isala Klinieken Zwolle, the Netherlands; ${ }^{2}$ Departments of Endocrinology, ${ }^{3 G e n e t i c s ~ a n d ~}{ }^{3}$ Surgical Oncology, University Medical \\ Center Groningen, University of Groningen, the Netherlands
}

Key words: medullary thyroid cancer, MEN 2, RET mutation

Corresponding author: J.W.B. de Groot, M.D. Ph.D., Department of Internal Medicine, Isala Klinieken Zwolle, PO Box 10400, 8000 GK Zwolle, the Netherlands, tel.: 0031-38-4247427, fax: 0031-38-4247676, e-mail: j.w.b.de.groot@isala.nl

Submitted: 24 July 2006

Accepted: 27 July 2006

\begin{abstract}
MTC is a rare neuroendocrine thyroid tumour accounting for $3 \%$ to $10 \%$ of all thyroid malignancies. It can occur in a sporadic and a hereditary clinical setting. Hereditary MTC may either occur alone (familial MTC, FMTC) or as part of multiple endocrine neoplasia (MEN) type 2A, or MEN 2B. These disorders are due to germline mutations in the RET (REarranged during Transfection) gene. In carriers of MEN 2B-associated RET mutations, prophylactic thyroidectomy is indicated before the first year of life. In the case of MEN 2Aassociated germline RET mutations with a high-risk profile, total thyroidectomy is warranted before the age of 2 years and certainly before the age of 4 years. At that age the risk of invasive MTC and metastases is acceptably low. Depending on the type of RET mutation, thyroidectomy can take place at an older age in patients with a lower risk profile. In case of elevated basal or stimulated serum calcitonin, preventive surgery including total thyroidectomy and central compartment dissection should be performed regardless of age. When MTC presents as a palpable tumour, total thyroidectomy should be combined with extensive lymph node dissection of levels II-V on both sides and level VI to prevent locoregional recurrences.
\end{abstract}

\section{Introduction}

In 1959, Hazard et al. described a case of thyroid carcinoma with a solid, non-follicular structure with amyloid in the stroma [1]. This tumour was called solid or medullary thyroid carcinoma. Since then, medullary thyroid cancer (MTC) has been regarded as a separate clinical and pathological entity that should be distinguished from differentiated thyroid carcinomas.

MTC is a tumour originating in the parafollicular C-cells. The parafollicular C-cells are dispersed inside the follicles of the thyroid gland between the basal layer and the follicular cells and produce a hormone called calcitonin. C-cells derive from the neural crest and are not related to the follicular cells. They account for about $1 \%$ of thyroid cells and are most numerous at the junction of the upper third and the lower two-thirds of the thyroid lobes.

MTC is a very rare neuroendocrine thyroid tumour accounting for $3 \%$ to $10 \%$ of all thyroid malignancies [2-4]. It can occur in a sporadic and a hereditary clinical setting. Hereditary MTC may either occur alone (familial MTC, FMTC) or as part of multiple endocrine neoplasia (MEN) type $2 \mathrm{~A}$, or MEN 2B. These disorders are due to germline mutations in the RET (REarranged during Transfection) gene [5-7]. 


\section{Histopathology}

Macroscopically, MTC is typically located in the upper two-thirds of the thyroid lobes. Usually it is solid in consistency and whitish or red in colour. Histologically, MTC consists of nests of predominantly round cells with abundant, finely granular amphophilic cytoplasm and ovoid to round nuclei. Occasional red cytoplasmic granules are seen, and the supporting stroma frequently stains for amyloid (these are in fact calcitonin deposits [8]). In practically all MTCs, immunohistochemical staining for calcitonin and carcino-embryonic antigen (CEA) is positive (Figure 1).

Hereditary MTC is generally bilateral and multifocal, whereas in sporadic MTC the tumour is most frequently unilateral. In addition, in practically all patients with

A

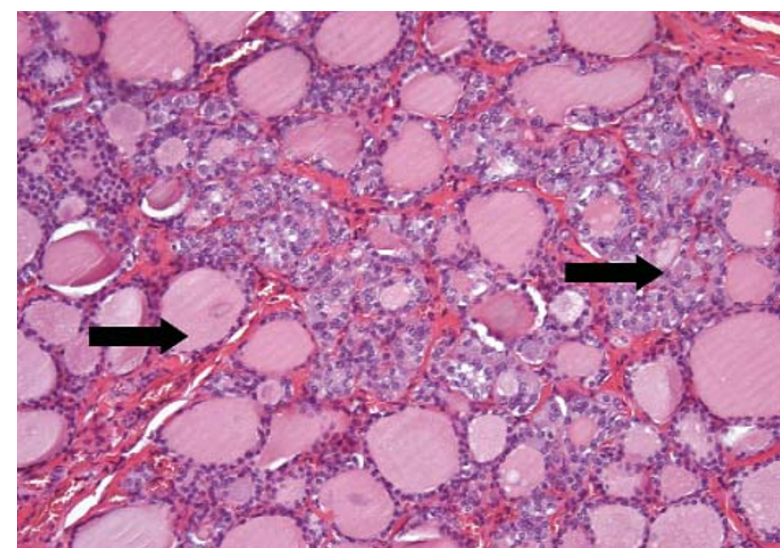

C

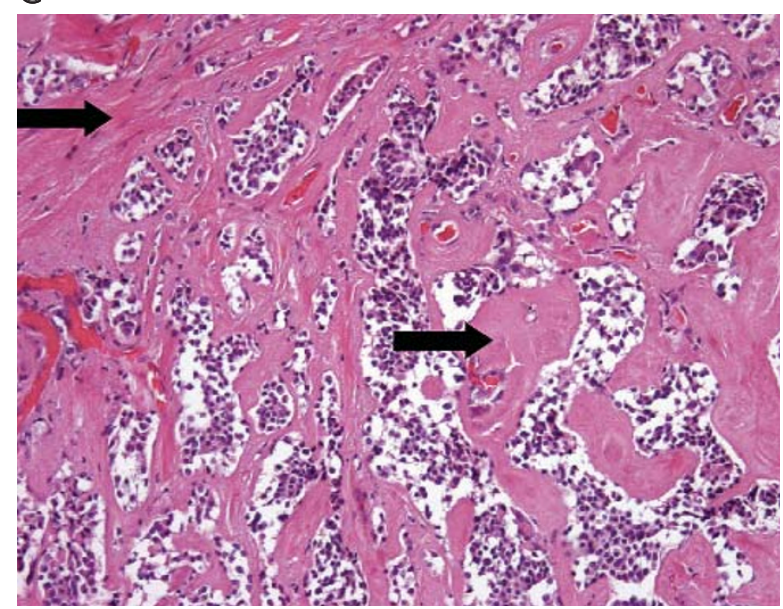

hereditary MTC, C-cell hyperplasia $(\mathrm{CCH})$ is present (Figure 1) [9]. Wolfe et al. were in 1973 the first to describe $\mathrm{CCH}$ as the presence of a multifocal increase and clustering of noninvasive calcitonin-containing cells in the absence of grossly visible tumour in two related patients with abnormally high serum levels of stimulated calcitonin [10]. Hereditary MTC develops stepwise via $\mathrm{CCH}$ (Figure 2). In addition, $\mathrm{CCH}$ accompanies (and probably precedes) a number of sporadic MTC but $\mathrm{CCH}$ is frequently absent in these cases [11]. Moreover, physiologic $\mathrm{CCH}$ is associated with inflammatory and metabolic thyroid disorders as well as with hypercalcaemia and in the general population it is present in $20 \%$ to $30 \%$ of normal (non-cancerous) thyroids [12].

Metastases to regional lymph nodes happen early in the course of disease and have frequently already occurred at the time of diagnosis. The central
B

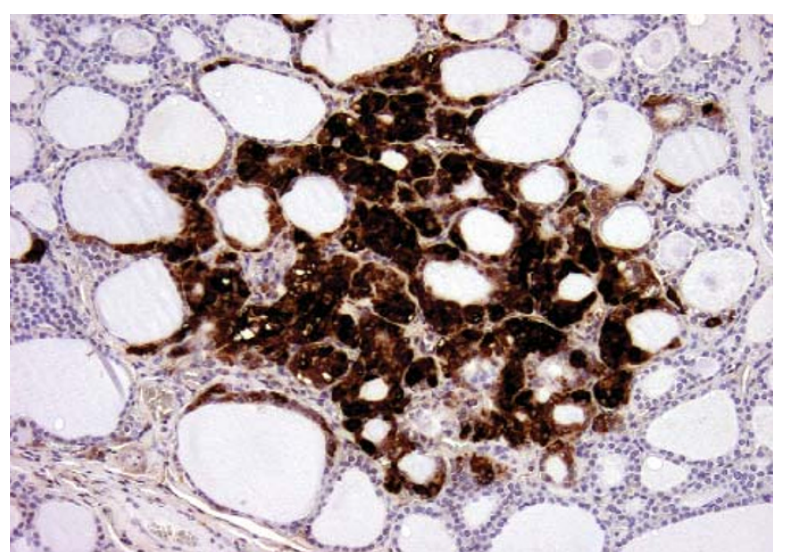

D

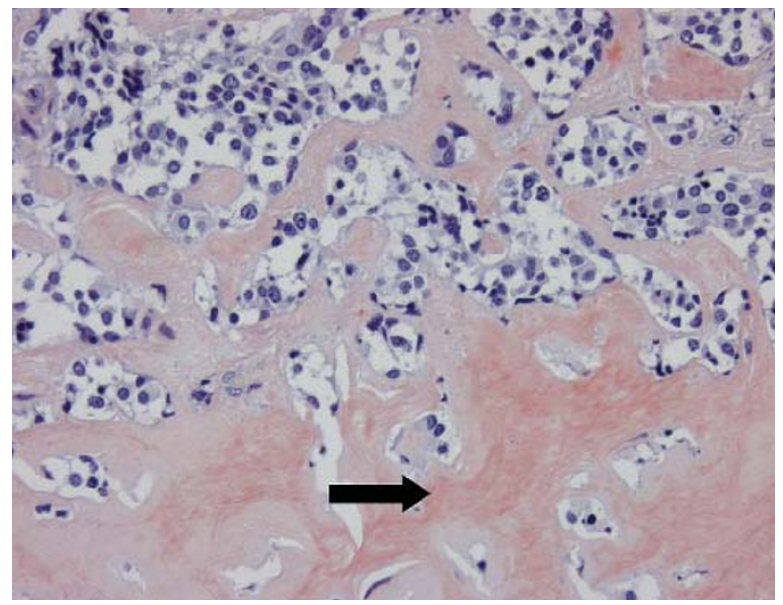

Fig. 1. [A] Microscopic view of normal thyroid tissue with hyperplastic C-cells (arrows) dispersed between the follicles. C-cell hyperplasia $(\mathrm{CCH})$ was defined as clusters of intrafollicular atypical C-cells (more than 50 per "low-power field" at 100x magnification) that lead to partial or complete obliteration of the follicular space. [B] C-cells are positive for immunohistochemical staining for calcitonin (dark areas). [C] Microscopic view of medullary thyroid cancer (MTC). Malignant C-cells have broken through the basement membrane and invaded the interstitium, which has led to stromal fibrosis (arrows). MTC lesions are composed of solid nests of epithelial cells with poorly defined cell borders. [D] Occasionally there is deposition of intensely eosinophilic material, amyloid, which can be stained with Congo-red (arrow). Amyloid is derived from calcitonin 
(paratracheal) lymph nodes are most often involved followed by the ipsilateral, contralateral (jugular) and mediastinal lymph nodes [13]. Distant metastases develop variably in the course of MTC, usually to the liver, lungs, and bone [3, 14].

\section{Secretion products}

MTC synthesizes and secretes a wide range of substances, the most abundant being calcitonin [15]. Calcitonin is a small 32 amino acid polypeptide hormone and the main biochemical marker used for detection and postoperative management of patients with MTC $[16,17]$. Elevated serum calcitonin levels are found in patients with MTC, CCH or, rarely, in patients without any $\mathrm{C}$-cell abnormalities. Patients with renal insufficiency, Hashimoto's thyroiditis and (metastatic) carcinoids can also have elevated serum calcitonin levels. In neonates, serum calcitonin levels are high but these levels decline to normal by one year of age [4, 18]. Generally, basal serum calcitonin roughly correlates with tumour burden, although there are exceptions, especially in patients with extensively metastasized MTC. Furthermore, in small tumours and $\mathrm{CCH}$ serum calcitonin levels may be normal. Calcitonin can then be stimulated by pentagastrin, calcium or omeprazole but pentagastrin is the provocative agent of choice [18-20].

Another tumour marker for MTC is CEA, which is mainly produced by neoplastic C-cells but also found in normal C-cells. Measurement of serum CEA levels is useful in the follow-up of MTC since rapidly increasing CEA levels can indicate dedifferentiation of the tumour [21, 22].

MTCs not only secrete calcitonin and CEA. Other secretion products include serotonin (causing carcinoid syndrome), prostaglandins, corticotropin releasing factor, adrenocorticotropic hormone (causing Cushing's syndrome), histaminase, and somatostatin (which may cause paraneoplastic clinical syndromes). Furthermore, MTC is known to produce several gastrointestinal hormones and neuroendocrine peptides, including calcitonin gene related peptide, chromogranin $A$, vasoactive intestinal peptide, and ghrelin [15].

There is increasing evidence for a subgroup of MTCs that do not secrete calcitonin, CEA or both, making tumour follow-up difficult [23-25]. Although calcitonin (and CEA) is not a perfect tumour marker, none of the other secretion products is comparable to calcitonin in terms of sensitivity and specificity.

\section{Clinical presentation}

Most patients with sporadic MTC present in the fourth or fifth decade of life with a painless thyroid

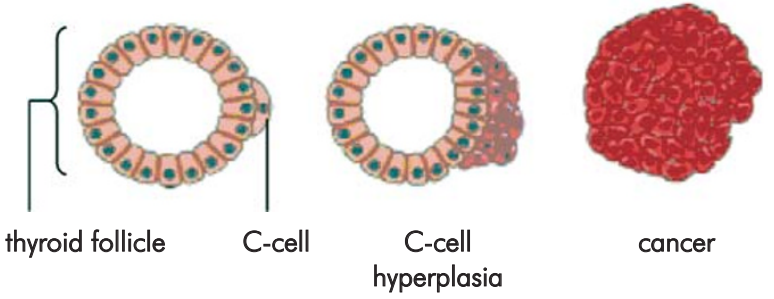

Fig. 2. Development of medullary thyroid cancer (MTC) from a normal C-cell via C-cell hyperplasia $(\mathrm{CCH})$ to MTC

nodule often accompanied by cervical lymphadenopathy (Figure 3). Sometimes patients have pain in the neck, dysphagia, respiratory difficulties, hoarseness or symptoms of ectopic hormone production such as diarrhoea, flushes or Cushing's syndrome [15]. Patients with hereditary MTC may also present with a neck mass. Additionally, patients with MEN 2 or FMTC may have symptoms characteristic of pheochromocytoma.

Fine-needle aspiration cytology (FNAC) can reveal the diagnosis prior to surgery, especially when immunohistochemical staining for calcitonin is performed, but FNAC may be inconclusive or only diagnose malignancy. Measurement of serum calcitonin may then be a complementary approach to make the final diagnosis [26]. However, if basal calcitonin is elevated, a pentagastrin stimulation test should always follow to confirm that the source of elevated calcitonin concentrations is indeed MTC.

\section{Sporadic and hereditary medullary thyroid cancer}

As mentioned earlier, MTC may be sporadic or hereditary. Sporadic MTC is the most common form of MTC, accounting for approximately $75 \%$ of all cases at initial presentation. The remaining $25 \%$ comprise hereditary MTC including MEN 2A (most common), MEN 2B, and FMTC (the least common) (Table 1).

In 1962 Sipple was the first to describe the association of MTC with pheochromocytoma and hyperparathyroidism [27]. In 1966 Williams and Pollock described the association between oral mucosal and eyelid neuromas, MTC, pheochromocytoma, and ganglioneuromatosis of the gastro-intestinal tract in a father and a daughter [28].

Two years later, in 1968, Steiner et al. introduced the term "multiple endocrine neoplasia" to describe different combinations of endocrine tumours. They designated the combination MTC, pheochromocytoma and parathyroid adenoma as MEN 2 [29]. Sizemore 
Table 1. Clinical expression of the variants of hereditary MTC associated syndromes

\begin{tabular}{lccc}
\hline & FMTC & MEN 2A & MEN 2B \\
\hline medullary thyroid cancer & $100 \%$ & $100 \%$ & $100 \%$ \\
\hline C-cell hyperplasia & $100 \%$ & $100 \%$ & $100 \%$ \\
\hline Pheochromocytoma & $0 \%$ & $10 \%$ to $60 \%$ & $50 \%$ \\
\hline Hyperparathyroidism & $0 \%$ & $10 \%$ to $25 \%$ & $0 \%$ \\
\hline Marfanoid habitus & $0 \%$ & $0 \%$ & $100 \%$ \\
\hline Intestinal ganglioneuromatosis & $0 \%$ & $0 \%$ & $60 \%$ to $90 \%$ \\
\hline Mucosal neuromas & $0 \%$ & $0 \%$ & $70 \%$ to $100 \%$ \\
\hline thick corneal nerves & $0 \%$ & Rare & $60 \%$ to $90 \%$ \\
\hline
\end{tabular}

FMTC, familial medullary thyroid cancer; MEN 2A/2B, multiple endocrine neoplasia type 2A/2B

et al. concluded in 1973 that the MEN 2 category included two distinct groups of patients with MTC and pheochromocytoma: patients with hyperparathyroidism and a normal physical appearance and patients without parathyroid disease but with marfanoid habitus, mucosal neuromas, and alimentary abnormalities. They suggested the title "MEN type 2B" for the group without parathyroid disease [30]. Subsequently, in 1975, Chong et al. proposed that the combination of MTC, pheochromocytoma, and parathyroid disease in patients with a normal appearance be referred to as MEN type $2 \mathrm{~A}[31]$.

A

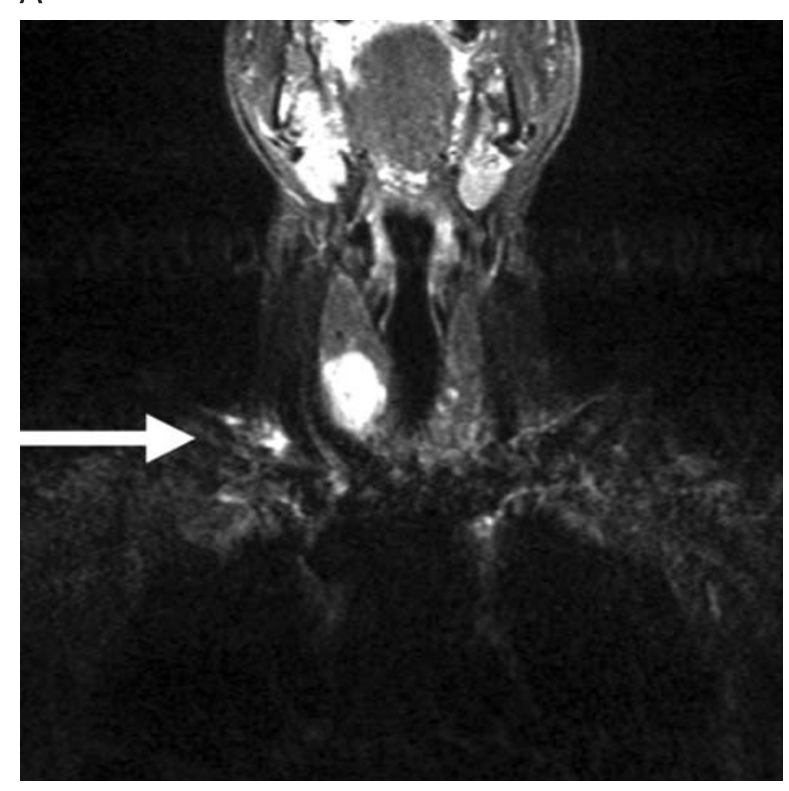

\section{Genetic background}

In 1993, characteristic germline mutations of the RET gene on chromosome 10 were shown to be responsible for the inherited forms of MTC [5-7]. RET contains 21 exons and encodes the transmembrane tyrosine kinase receptor RET (Figure 4). In patients with a family history of MEN 2 or FMTC, it is now possible to determine the risk of MTC by genetic screening. As it is a dominantly inherited disease, about $50 \%$ of family members do not carry a germline RET mutation. Family members with a RET mutation have a $100 \%$ risk

\section{B}

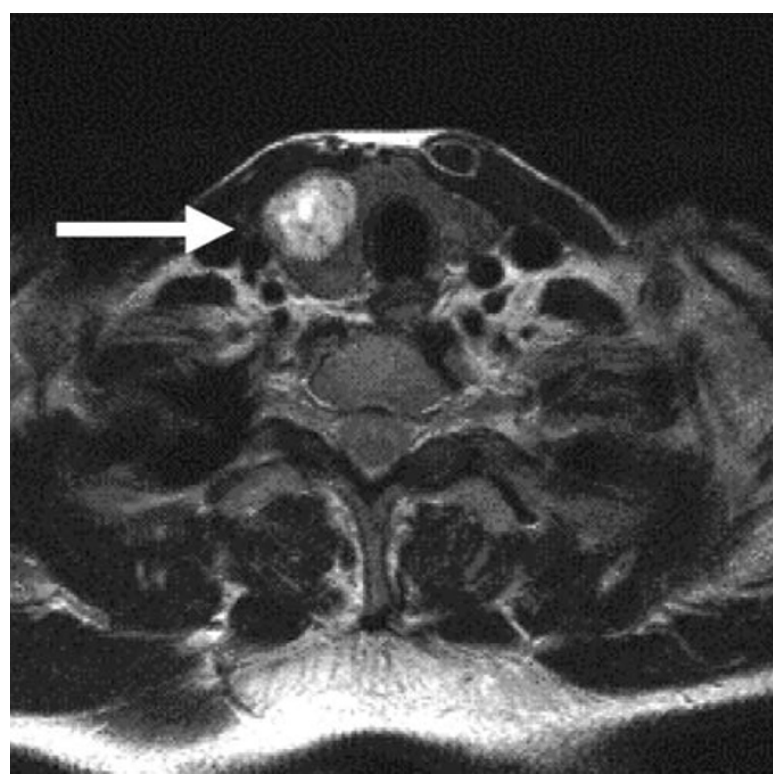

Fig. 3. Magnetic Resonance Imaging (MRI) of the neck of a 51 -year-old woman with a germline V804L RET mutation demonstrating a thyroid nodule (arrow on the right) and cervical lymphadenopathy (arrow on the left) 
of developing MTC, whereas family members that do not carry a RET mutation have a risk that is similar to the general population. In patients with apparently sporadic MTC germline RET mutations are found in $4 \%$ to $10 \%$ of cases [4]. In up to $30 \%$ of patients with sporadic MTC, somatic mutations (occurring only in the tumour) in RET are present [32].

Before 1993, screening for hereditary MTC consisted primarily of family history followed by testing for elevated basal and pentagastrin stimulated serum calcitonin levels to identify asymptomatic gene carriers. This method requires frequent screening and the main disadvantage is that it is impossible to distinguish between asymptomatic gene carriers and family members that will never develop MTC. Furthermore, there is a risk of false-positive test results leading to unnecessary thyroidectomy and it is not possible to distinguish between $\mathrm{CCH}$ and invasive cancer [33, 34].

After 1993, DNA testing was used to classify MTC as being of the inherited type and to identify relatives of patients with a mutated RET gene prior to the development of clinical and biochemical signs of the disease. Using DNA analysis, a reliable estimation of the risk of MTC can be given since all patients with a germline RET mutation will eventually develop MTC. Identification of the type of RET mutation has led to the implementation of early prophylactic thyroidectomy [35].

\section{Treatment}

Management of MTC is primarily surgical. MTC does not respond to standard chemotherapeutic regimens and external beam radiotherapy has a limited effect in selected groups of patients. Moreover, treatment with radioactive iodine is of no significant value since C-cells do not take up iodine [15, 32].

Due to the high likelihood of a familial component and the risks of other tumours associated with MEN 2, all patients with MTC should be genetically screened for RET mutations. Furthermore, a systematic work-up for pheochromocytoma including 24-hour urine collection for catecholamines and metabolites should be performed. Pheochromocytomas need to be treated before undertaking surgery for MTC in order to avoid a potentially lethal intraoperative hypertensive crisis. Patients with possible MEN 2A should also have serum calcium and possible parathormone levels evaluated to rule out hyperparathyroidism.

In recent years great progress has been made regarding genotype-phenotype correlations in MEN 2 and FMTC. Based on the biological behaviour of MTC observed in patients with a germline RET mutation, a codon-specific estimation of the risk for MTC can be

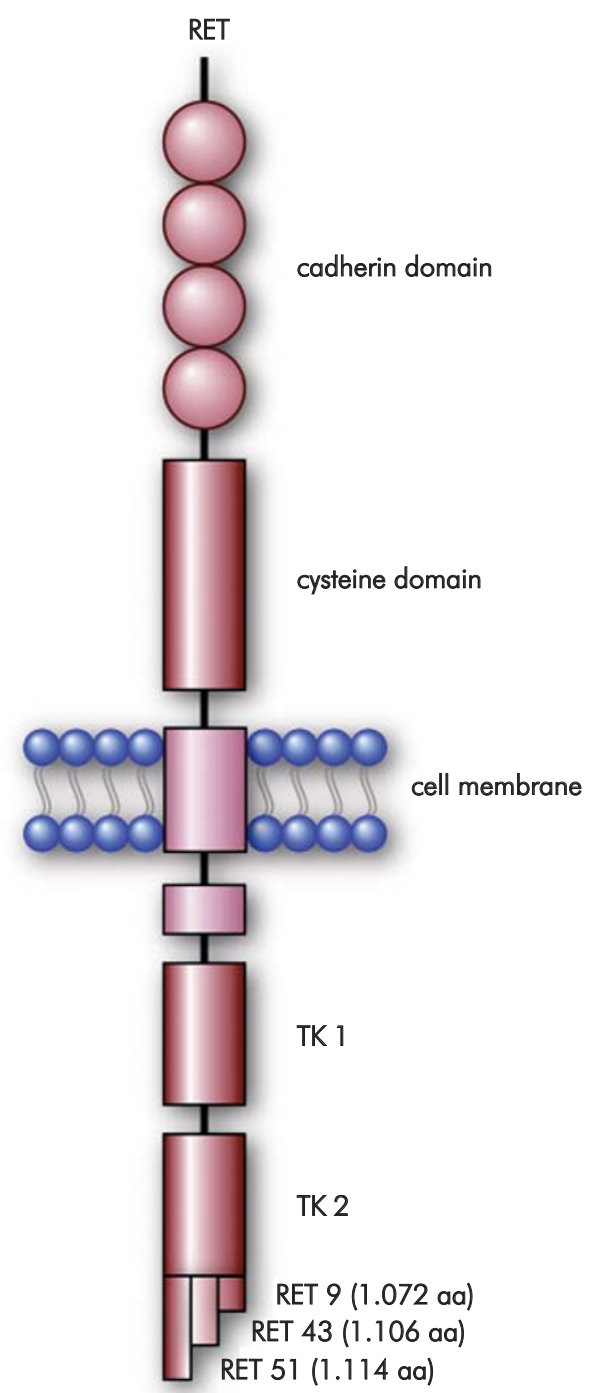

Fig. 4. Copyright 2006, The Endocrine Society. Schematic representation of the RET tyrosine kinase. The extracellular region comprises four cadherin domains and a cysteine rich domain. A single transmembrane region spans the cell membrane, and the two tyrosine kinase domains (TK1 and TK2) are located in the intracellular region. There are three isoforms of RET (RET9, RET43, RET 51) which are indicated. aa, Amino acids. [Adapted from De Groot et al. [35]]

made (Table 2). Figure 5 shows an overview of the known germline mutations of RET. In MEN 2A the most frequent mutations are found in exons 10 and 11 on codons 609, 611, 618, 620, 630 and 634. Mutations in exons 13, 14, and 15 on codons 768, 790, 791, 804 and 891 and mutations in codon 666 on exon 11 are very rare. In FMTC mutations are found in the same codons as in MEN 2A except for FMTC-specific mutations in codons 533 (exon 8), 600, 603, 606, $649,778,781,852$ and 912 but they are more evenly 


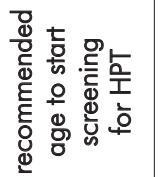

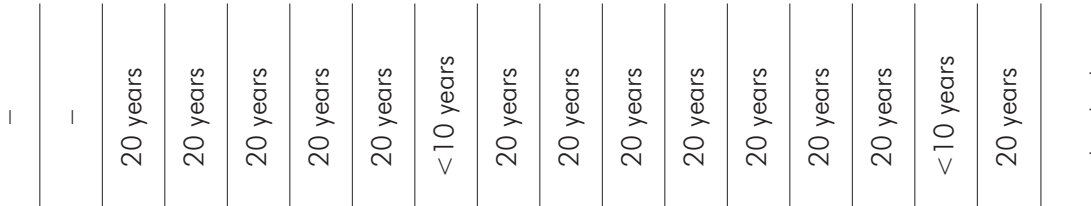

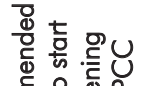

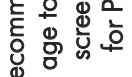

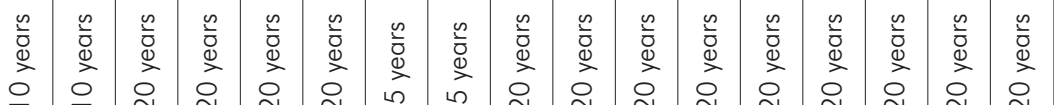

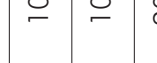

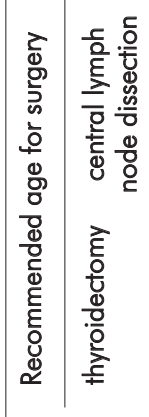

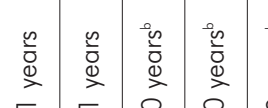

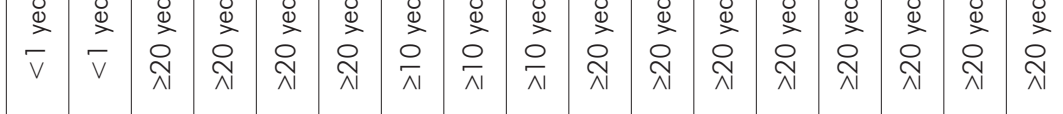

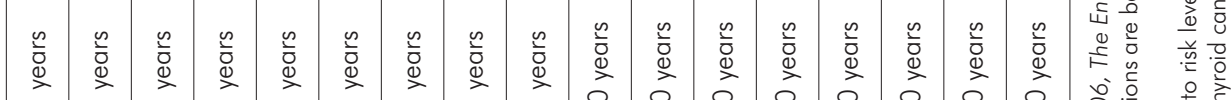

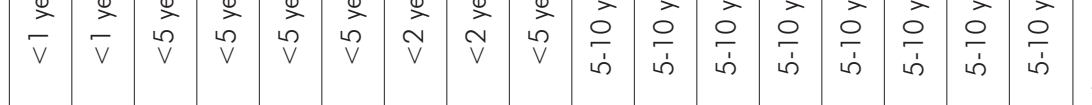

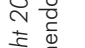

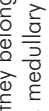

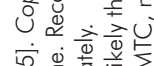

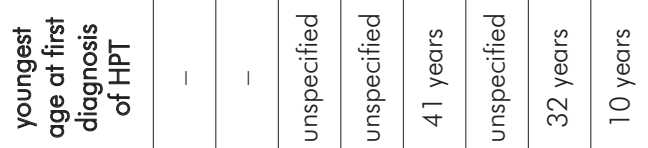

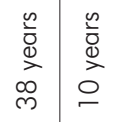

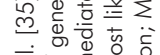

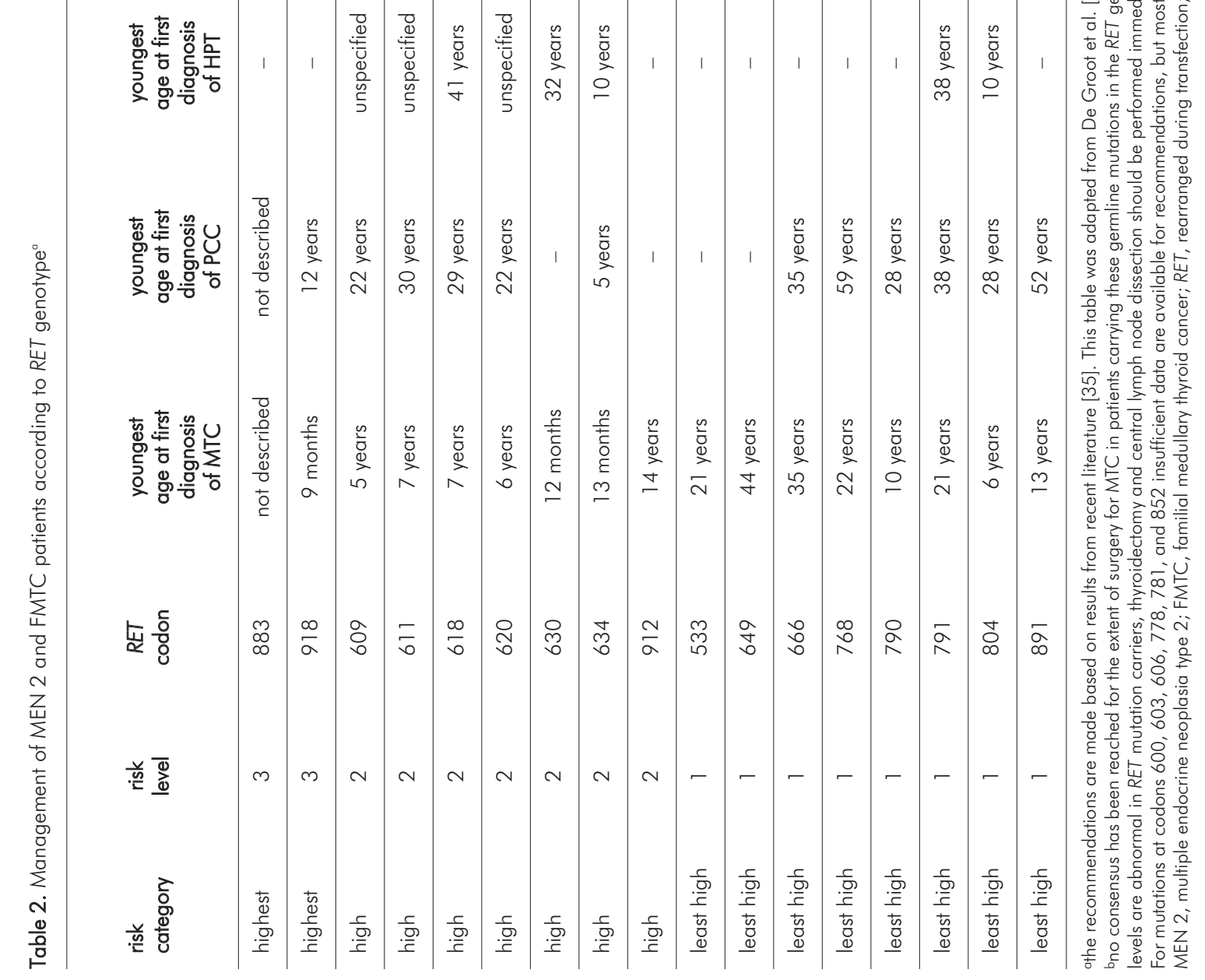




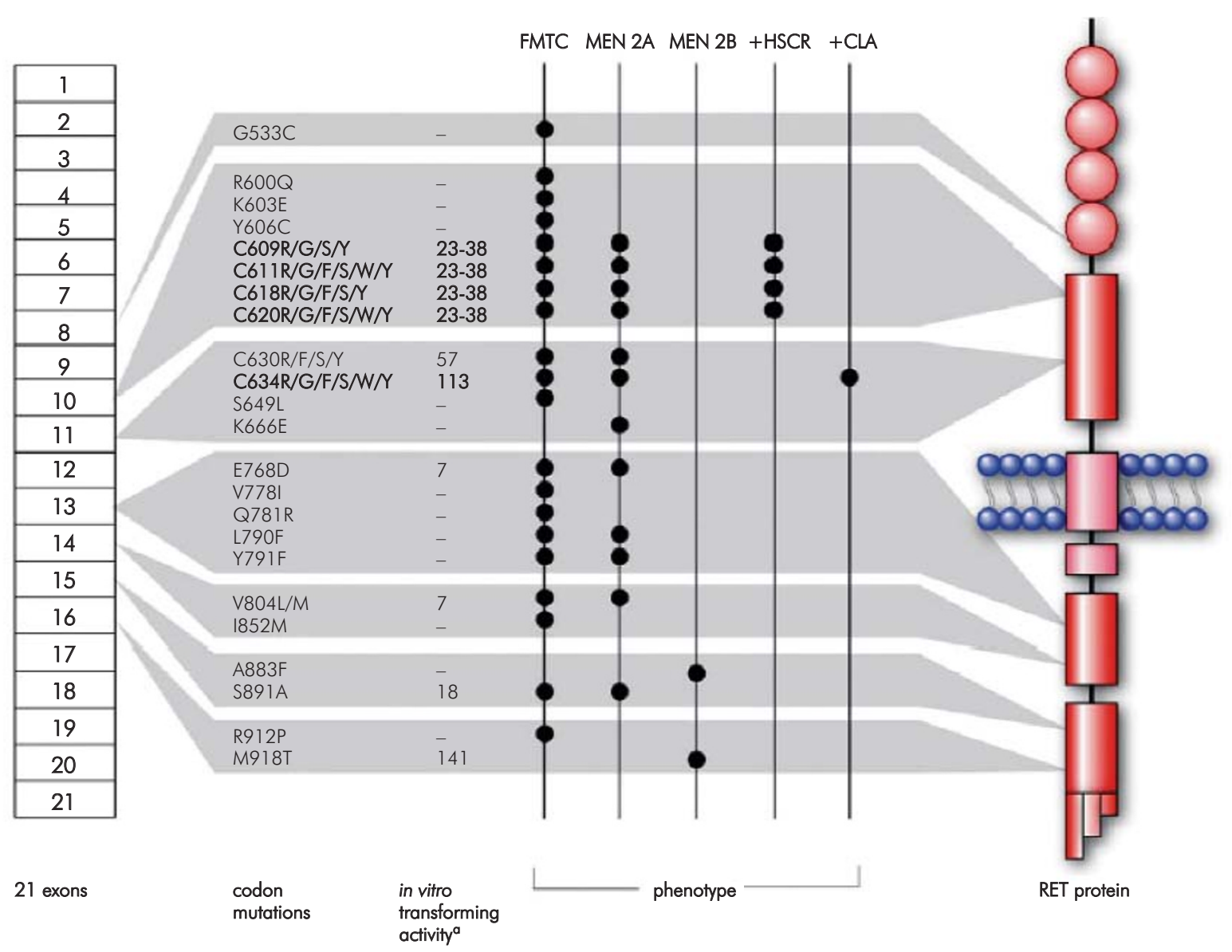

Fig. 5. Copyright 2006, The Endocrine Society. Overview of the known germline missense mutations in the RET gene and their associated human diseases. The structure of the RET mRNA and the RET protein are depicted schematically. The mutations responsible for the diverse inherited cancer syndromes and the location of the mutations relative to the exons and the functional domains are shown. The most common mutations that are found in about 95\% of MEN 2A and FMTC cases are depicted in bold, and MEN 2B mutations are depicted in italics. CLA, Cutaneous lichen amyloidosis. [Adapted from De Groot et al. [35]]

divided among the different exons. In MEN 2B mutations are almost always found in exon 16 (codons 883, 918) [35]. In the Netherlands exons 10, 11, 13, 14,15 and 16 are routinely screened for germline mutations when a form of hereditary MTC is suspected. In case of a strong suspicion of inherited MTC and the absence of mutations in exons 10, 11, 13, 14, 15 and 16, screening of exon 8 may be considered.

In the University Medical Center of Groningen, 21 children with MEN 2A underwent prophylactic thyroidectomy. The clinical characteristics are summarized in Table 3. MTC was already present at the age of three years, and in the literature MEN 2A-associated MTC is described at the age of one year [36]. Therefore, early surgical intervention in patients with an RET mutation is warranted.

Carriers of a germline RET mutation sooner or later will develop MTC and surgery is the only curatively intended treatment of this form of cancer. The turning point of progression from $\mathrm{CCH}$ into invasive MTC is as yet unknown. When surgery takes place at a young age (at the age of three or four years) the risk of invasive MTC is low and the extent of surgery can be minimal (only a total thyroidectomy) with low risk of hypoparathyroidism or paralysis of the recurrent laryngeal nerve.

In our patients, 20 of 21 patients had C-cell disease and in five of seven patients (71\%) younger than five years old (the youngest being three years old) MTC was already present. Based on the youngest age at which MTC was already present a total thyroidectomy seems warranted before the age of two in carriers of RET mutations in codons 630 and 634 (Table 2). However, it should be noted that all patients with such a mutation who have been operated on around the age of 4 years were biochemically cured [35].

The prognosis of MTC attenuates with the presence of lymph node metastases [36]. Therefore it is crucial that prophylactic thyroidectomy is performed before the 
Table 3. Occurrence of MTC related to patient characteristics and type of RET gene mutation in children who underwent prophylactic thyroidectomy for multiple endocrine neoplasia type 2A

\begin{tabular}{|c|c|c|c|c|c|c|c|}
\hline $\begin{array}{l}\text { Patient/ } \\
\text { family }\end{array}$ & $\begin{array}{c}\text { Year } \\
\text { of surgery }\end{array}$ & Sex & $\begin{array}{l}\text { Age } \\
\text { (year) }\end{array}$ & $\begin{array}{l}\text { Type of RET } \\
\text { mutation }\end{array}$ & $\begin{array}{l}\text { Calcitonin (ng/L) } \\
\text { Basal/Stimulated }^{\circ}\end{array}$ & $\begin{array}{c}\text { Lymph node } \\
\text { dissection (initially) }\end{array}$ & Histology \\
\hline $1 / \mathrm{A}$ & 1976 & M & 17 & M918 $8 \mathrm{~T}^{\mathrm{b}}$ & - & $\begin{array}{c}\text { central and } \\
\text { unilateral (level II-V) }\end{array}$ & multifocal MTC; positive lymph nodes \\
\hline $2 / B$ & 1998 & $\mathrm{~F}$ & 18 & C634G & $2000 / 31600$ & central & multifocal MTC; positive lymph nodes \\
\hline $3 / C$ & 1999 & M & 14 & C634R & $151 / 1200$ & central & multifocal MTC; positive lymph nodes \\
\hline 4/D & 1977 & $\mathrm{~F}$ & 18 & C634R & - & central & multifocal MTC \\
\hline $5 / \mathrm{D}$ & 1978 & M & 17 & C634R & $489 /-$ & central & multifocal MTC \\
\hline $6 / E$ & 1995 & $\mathrm{~F}$ & 5 & C634R & $61 / 198$ & central exploration & multifocal MTC \\
\hline $7 / \mathrm{C}$ & 1999 & $\mathrm{~F}$ & 12 & C634R & $12 / 125$ & central exploration & multifocal MTC \\
\hline $8 / F$ & 2000 & $\mathrm{~F}$ & 5 & C634Y & $34 /-$ & central exploration & multifocal MTC \\
\hline 9/B & 2004 & $\mathrm{~F}$ & 3 & C634G & $72 / 188$ & central & multifocal MTC \\
\hline $10 / G$ & 2005 & $\mathrm{~F}$ & 11 & C634R & 13/- & central & multifocal MTC \\
\hline $11 / F$ & 1995 & $F$ & 11 & C634Y & $24 / 122$ & central exploration & unifocal MTC \\
\hline $12 / \mathrm{H}$ & 1999 & M & 4 & C634R & $5 / 384$ & - & unifocal MTC \\
\hline 13/1 & 2000 & $\mathrm{~F}$ & 6 & C620R & $15 /-$ & central & unifocal MTC \\
\hline $14 / J$ & 1995 & $\mathrm{~F}$ & 4 & C634W/R635G & $18 / 447$ & central & unifoclal MTC \\
\hline $15 / J$ & 1990 & $\mathrm{~F}$ & 14 & C634W/R635G & $632 /-$ & - & $\mathrm{CCH}$ \\
\hline $16 / K$ & 1990 & $\mathrm{~F}$ & 7 & C634R & $63 /-$ & central exploration & $\mathrm{CCH}$ \\
\hline $17 / K$ & 1990 & M & 10 & C634R & $92 /-$ & central & $\mathrm{CCH}$ \\
\hline $18 / F$ & 1995 & M & 11 & C634Y & 79/177 & central exploration & $\mathrm{CCH}$ \\
\hline 19/F & 2004 & $\mathrm{~F}$ & 1 & C634Y & $48 /-$ & central & $\mathrm{CCH}$ \\
\hline $20 / L$ & 2005 & M & 16 & V804L & $13 / 32$ & central & $\mathrm{CCH}$ \\
\hline $21 / 1$ & 1997 & $F$ & 5 & C620R & 13/- & - & no $C$-cell disease \\
\hline
\end{tabular}

abefore 2001 the reference value was $<50 \mathrm{ng} / \mathrm{L}$, after 2001 the reference value was $<12 \mathrm{ng} / \mathrm{L}$;

bpatient with multiple endocrine neoplasia type $2 \mathrm{~B}$;

RET - rearranged during transfection; $\mathrm{F}$ - female; $\mathrm{CCH}$ - C-cel hyperplasia; $\mathrm{M}$ - male; MTC - medullary thyroid carcinoma

development of MTC and possible node metastases. In adults with MTC, lymph node metastases are already present in about $50 \%$ of cases, even in tumours smaller than $1 \mathrm{~cm}$. However, in children without symptoms in whom a RET mutation is detected via genetic screening lymph node metastases infrequently occur [36, 37].

There is still no 'gold standard' concerning the extent of lymph node dissection that should be performed in addition to total thyroidectomy [38]. Furthermore, it is controversial from what age to perform a lymph node dissection. The results of this study confirm the data of others in which lymph node metastases in patients with MEN 2A and FMTC are almost always found after the age of 10 years. Patients with an RET mutation in codon 630 or 634 hardly ever have metastases before the age of 10 years and patients with mutations in codons 609, $611,618,620,768,790,791,804$ and 891 rarely have metastases before the age of 20 years [36, 37]. Until the age of 10 years, a total thyroidectomy should be sufficient in patients with MEN 2A or FMTC. However, several patients younger than 10 years old have been described with lymph node metastases. The risk of invasive MTC and possible nodal metastases is present in the case of elevated serum calcitonin levels as recently illustrated by Van Santen and colleagues [39]. For that reason, a central compartment dissection in addition to 
total thyroidectomy to remove possible occult lymph node metastases is indicated when basal or stimulated serum calcitonin levels are elevated (Table 2) [35, 36].

Careful preservation of recurrent nerves and parathyroid glands may be difficult in very young children. The risk of injuring recurrent nerves at risk after thyroid surgery in the literature varies between $0 \%$ and $4 \%$ and symptomatic hypoparathyroidism with calcium supplementation occurs in $0 \%$ to $21 \%$ [40-56]. The incidence of complications strongly depends on the experience of the surgeon $[44,50,57]$. Hence, thyroid surgery in children should be performed in a referral centre with large experience in this form of surgery. Total thyroidectomy and central compartment dissection is then relatively safe. Even with meticulous dissection however, the blood supply to the parathyroid glands may be impaired. In these circumstances autotransplantation after microscopic verification may reduce the incidence of hypoparathyroidism [40, 41, 47].

The risk of bilateral lymph node metastases is high in patients who present with a palpable thyroid nodule or nodal metastases (the majority of patients with sporadic MTC). In these cases, elective bilateral selective neck dissection of level II to $\mathrm{V}$ is recommended in addition to total thyroidectomy and central compartment dissection [36]. In children with MEN 2B the risk of node metastases is very high and total thyroidectomy with central compartment dissection is justified in the first year of life $[36,37,48]$.

\section{Prognosis and follow-up}

The prognosis of patients with MTC varies considerably: some patients survive several decades with persistent MTC, whereas others die within months of initial presentation [3, 14]. Five and 10-year overall survival rates in patients with MTC without the presence of distant metastases at initial diagnosis range from $70 \%$ to $90 \%$ and $60 \%$ to $80 \%$, respectively $[14,58-60]$. When matched for age and extent of disease, no differences in survival were seen in patients with either hereditary or sporadic MTC but MEN 2B-associated MTC has been reported to be more aggressive than MTC associated with MEN 2A or FMTC [3, 59]. In multivariate analysis, only the patients' stage of disease at diagnosis is a significantly independent indicator of survival [60].

Patients with normal basal and stimulated serum calcitonin levels are likely to be cured. However, in approximately $5 \%$ of these patients, serum calcitonin levels can rise again during follow-up [4]. Currently, the only treatment option in patients with detectable serum calcitonin levels after initial treatment is reoperation. Yet re-operation can only be with curative intent in the absence of distant metastases when residual or recurrent MTC is confined to the neck. In patients with postoperative hypercalcitoninemia, the source of calcitonin production is hard to identify with conventional medical imaging and distant metastases cannot be reliably ruled out [61]. When distant metastases are present, therapeutic options are limited.

\section{Conclusion}

MTC can occur in a sporadic form and as part of the hereditary cancer syndromes MEN 2A/B or FMTC. In carriers of MEN 2B-associated RET mutations, prophylactic thyroidectomy is indicated before the first year of life. In case of MEN 2A-associated germline RET mutations with a high-risk profile, total thyroidectomy is warranted before the age of 2 years and certainly before the age of 4 years. At that age the risk of invasive MTC and metastases is acceptably low. Depending on the type of RET mutation, thyroidectomy can be performed at an older age in patients with a lower risk profile. In case of elevated basal or stimulated serum calcitonin preventive surgery including total thyroidectomy and central compartment dissection should in any case be performed at any age. When MTC presents as a palpable tumour, total thyroidectomy should be combined with extensive lymph node dissection of levels II-V on both sides and level VI to prevent locoregional recurrences. This kind of surgery can be performed relatively safely by well-experienced surgeons.

\section{References}

1. Hazard JB, Hawk WA and Crile Jr G. Medullary (solid) carcinoma of the thyroid; a clinicopathologic entity. J Clin Endocrinol Metab 1959; 19: 152-161.

2. Hundahl SA, Fleming ID, Fremgen AM and Menck HR. A National Cancer Data Base report on 53,856 cases of thyroid carcinoma treated in the U.S., 1985-1995 [see comments]. Cancer 1998; 83: 2638-2648.

3. Kebebew E, Ituarte PH, Siperstein AE, Duh QY and Clark OH. Medullary thyroid carcinoma: clinical characteristics, treatment, prognostic factors, and a comparison of staging systems. Cancer 2000; 88: 1139-1148.

4. Leboulleux S, Baudin E, Travagli JP and Schlumberger M. Medullary thyroid carcinoma. Clin Endocrinol (Oxf) 2004; 61: 299-310.

5. Mulligan LM, Kwok JB, Healey CS, Elsdon MJ, Eng C, Gardner E, Love DR, Mole SE, Moore JK, Papi L, et al. Germ-line mutations of the RET proto-oncogene in multiple endocrine neoplasia type 2A. Nature 1993; 363: 458-460.

6. Donis-Keller H, Dou S, Chi D, Carlson KM, Toshima K, Lairmore TC, Howe JR, Moley JF, Goodfellow P and Wells SA Jr. Mutations in the RET proto-oncogene are associated with MEN 2A and FMTC. Hum Mol Genet 1993; 2: 851-856.

7. Hofstra RM, Landsvater RM, Ceccherini I, Stulp RP, Stelwagen T, Luo Y, Pasini B, Hoppener JW, van Amstel HK, Romeo G, et al. A mutation in the RET proto-oncogene associated with multiple 
endocrine neoplasia type $2 \mathrm{~B}$ and sporadic medullary thyroid carcinoma. Nature 1994; 367: 375-376.

8. Khurana R, Agarwal A, Bajpai VK, Verma N, Sharma AK, Gupta RP and Madhusudan KP. Unraveling the amyloid associated with human medullary thyroid carcinoma. Endocrinology 2004; 145 : 5465-5470.

9. Livolsi VA. C cell hyperplasia/neoplasia. J Clin Endocrinol Metab 1997; 82: 39-41

10. Wolfe HJ, Melvin KE, Cervi-Skinner SJ, Saadi AA, Juliar JF Jackson CE and Tashiian AH Jr. C-cell hyperplasia preceding medullary thyroid carcinoma. N Engl J Med 1973; 289: 437 441.

11. Guyetant S, Josselin N, Savagner F, Rohmer V, Michalak S and Saint-Andre JP. C-cell hyperplasia and medullary thyroid carcinoma: clinicopathological and genetic correlations in 66 consecutive patients. Mod Pathol 2003; 16: 756-763.

12. Guyetant S, Rousselet MC, Durigon M, Chappard D, Franc B, Guerin $\bigcirc$ and Saint-Andre JP. Sex-related $C$ cell hyperplasia in the normal human thyroid: a quantitative autopsy study. J Clin Endocrinol Metab 1997; 82: 42-47.

13. Quayle FJ and Moley JF. Medullary thyroid carcinoma: including MEN 2A and MEN 2B syndromes. J Surg Oncol 2005; 89: 122-129.

14. Saad MF, Ordonez NG, Rashid RK, Guido JJ, Hill CS Jr, Hickey RC and Samaan NA. Medullary carcinoma of the thyroid. A study of the clinical features and prognostic factors in 161 patients. Medicine (Baltimore) 1984; 63: 319-342.

15. Orlandi F, Caraci P, Mussa A, Saggiorato E, Pancani G and Angeli A. Treatment of medullary thyroid carcinoma: an update. Endocr Relat Cancer 2001; 8: 135-147.

16. Tashiian AH, Jr. and Melvin EW. Medullary carcinoma of the thyroid gland. Studies of thyrocalcitonin in plasma and tumour extracts. N Engl J Med 1968; 279: 279-283.

17. Goltzman D, Potts JT, Jr., Ridgway RC and Maloof F. Calcitonin as a tumour marker. Use of the radioimmunoassay for calcitonin in the postoperative evaluation of patients with medullary thyroid carcinoma. N Engl J Med 1974; 290: 1035-1039.

18. Karanikas G, Moameni A, Poetzi C, Zettinig G, Kaserer K, Bieglmayer C, Niederle B, Dudczak R and Pirich C. Frequency and relevance of elevated calcitonin levels in patients with neoplastic and nonneoplastic thyroid disease and in healthy subjects. J Clin Endocrinol Metab 2004; 89: 515-519.

19. Gharib H, Kao PC and Heath H, III. Determination of silicapurified plasma calcitonin for the detection and management of medullary thyroid carcinoma: comparison of two provocative tests. Mayo Clin Proc 1987; 62: 373-378.

20. Vitale G, Ciccarelli A, Caraglia M, Galderisi M, Rossi R, Del Prete $S$, Abbruzzese $A$ and Lupoli $G$. Comparison of two provocative tests for calcitonin in medullary thyroid carcinoma: omeprazole vs pentagastrin. Clin Chem 2002; 48: 1505-1510.

21. Busnardo B, Girelli ME, Simioni N, Nacamulli D and Busetto E. Nonparallel patterns of calcitonin and carcinoembryonic antigen levels in the follow-up of medullary thyroid carcinoma. Cancer 1984; 53: 278-285.

22. Mendelsohn G, Wells SA, Jr. and Baylin SB. Relationship of tissue carcinoembryonic antigen and calcitonin to tumour virulence in medullary thyroid carcinoma. An immunohistochemical study in early, localized, and virulent disseminated stages of disease. Cancer 1984; 54: 657-662.

23. Sobol RE, Memoli V and Deftos LJ. Hormone-negative, chromogranin A-positive endocrine tumours. N Engl J Med 1989; 320: 444-447.

24. Redding $A H$, Levine $S N$ and Fowler MR. Normal preoperative calcitonin levels do not always exclude medullary thyroid carcinoma in patients with large palpable thyroid masses. Thyroid 2000; 10: 919-922.

25. Bockhorn M, Frilling A, Rewerk S, Liedke M, Dirsch $\bigcirc$, Schmid KW and Broelsch CE. Lack of elevated serum carcinoembryonic antigen and calcitonin in medullary thyroid carcinoma. Thyroid 2004; 14: 468-470.

26. Bugalho MJ, Santos JR and Sobrinho L. Preoperative diagnosis of medullary thyroid carcinoma: fine needle aspiration cytology as compared with serum calcitonin measurement. J Surg Oncol 2005; 91 : 56-60.

27. Sipple JH. The association of pheochromocytoma with carcinoma of the thyroid gland. Am J Med 1961; 31 : 163-166.

28. Williams ED and Pollock DJ. Multiple mucosal neuromata with endocrine tumours: a syndrome allied to von Recklinghausen's disease. J Pathol Bacteriol 1966; 91: 71-80.

29. Steiner AL, Goodman AD and Powers SR. Study of a kindred with pheochromocytoma, medullary thyroid carcinoma, hyperparathyroidism and Cushing's disease: multiple endocrine neoplasia, type 2. Medicine (Baltimore) 1968; 47: 371-409.

30. Carney JA. Familial multiple endocrine neoplasia: the first 100 years. Am J Surg Pathol 2005; 29: 254-274.

31. Chong GC, Beahrs OH, Sizemore GW and Woolner LH. Medullary carcinoma of the thyroid gland. Cancer 1975; 35: 695-704

32. Vitale G, Caraglia M, Ciccarelli A, Lupoli G, Abbruzzese A, Tagliaferri $P$ and Lupoli $G$. Current approaches and perspectives in the therapy of medullary thyroid carcinoma. Cancer 2001; 91: 1797-1808.

33. Telander RL, Zimmerman D, van Heerden JA and Sizemore GW. Results of early thyroidectomy for medullary thyroid carcinoma in children with multiple endocrine neoplasia type 2. J Pediatr Surg 1986; 21 : 1190-1194.

34. Lips CJ, Landsvater RM, Hoppener JW, Geerdink RA, Blijham $G$, van Veen JM, van Gils AP, de Wit MJ, Zewald RA, Berends MJ, et al. Clinical screening as compared with DNA analysis in families with multiple endocrine neoplasia type $2 A$. N Engl J Med 1994; 331 : 828-835.

35. de Groot JW, Links TP, Plukker JT, Lips CJ and Hofstra RM. RET as a diagnostic and therapeutic target in sporadic and hereditary endocrine tumours. Endocr Rev 2006; 27: 535-560.

36. Machens A, Ukkat J, Brauckhoff M, Gimm $\bigcirc$ and Dralle $H$. Advances in the management of hereditary medullary thyroid cancer. J Intern Med 2005; 257: 50-59.

37. Machens A, Niccoli-Sire P, Hoegel J, Frank-Rave K, van Vroonhoven TJ, Roeher HD, Wahl RA, Lamesch P, Rave F, ConteDevolx B, Dralle H; European Multiple Endocrine Neoplasia (EUROMEN) Study Group. Early malignant progression of hereditary medullary thyroid cancer. N Engl J Med 2003; 349: 1517-1525.

38. Brandi ML, Gagel RF, Angeli A, Bilezikian JP, Beck-Peccoz P, Bordi C, Conte-Devolx B, Falchetti A, Gheri RG, Libroia A, Lips CJ, Lombardi G, Mannelli M, Pacini F, Ponder BA, Rave F, Skogseid B, Tamburrano G, Thakker RV, Thompson NW, Tomassetti P, Tonelli F, Wells SA Jr and Marx SJ. Guidelines for diagnosis and therapy of MEN type 1 and type 2. J Clin Endocrinol Metab 2001; 86: 5658-5671.

39. van Santen HM, Aronson DC, van Trotsenburg AS, ten Kate FJ, van de Wetering MD, Wiersinga WM, de Vijlder JJ and Vulsma T. Disseminated Medullary Thyroid Carcinoma Despite Early Thyroid Surgery in the Multiple Endocrine Neoplasia-2A Syndrome. Thyroid 2005; 15: 485-488.

40. Decker RA, Geiger JD, Cox CE, Mackovjak M, Sarkar M and Peacock ML. Prophylactic surgery for multiple endocrine neoplasia type Ila after genetic diagnosis: is parathyroid transplantation indicated? World J Surg 1996; 20: 814-820. 
41. Skinner MA, Norton JA, Moley JF, DeBenedetti MK and Wells SA, Jr. Heterotopic autotransplantation of parathyroid tissue in children undergoing total thyroidectomy. J Pediatr Surg 1997; 32: $510-513$.

42. Frank-Rave K, Hoppner W, Buhr H, Herfarth C and Rave F. Results and follow-up in eleven MEN 2A gene carriers after prophylactic thyroidectomy. Exp Clin Endocrinol Diabetes 1997; 105 Suppl 4: 76-78.

43. Hotz HG, Runkel NS, Frank-Raue K, Raue F and Buhr HJ. Prophylactic thyroidectomy in MEN IIA: does the calcitonin level correlate with tumour spread? Langenbecks Arch Surg 1998; 383: 170-173.

44. Dralle H, Gimm O, Simon D, Frank-Rave K, Gortz G, Niederle B, Wahl RA, Koch B, Walgenbach S, Hampel R, Ritter MM, Spelsberg F, Heiss A, Hinze R and Hoppner W. Prophylactic thyroidectomy in 75 children and adolescents with hereditary medullary thyroid carcinoma: German and Austrian experience. World J Surg 1998; 22: 744-750.

45. Wells SA, Jr. and Skinner MA. Prophylactic thyroidectomy, based on direct genetic testing, in patients at risk for the multiple endocrine neoplasia type 2 syndromes. Exp Clin Endocrinol Diabetes 1998; 106: 29-34.

46. Lallier M, St-Vil D, Giroux M, Huot C, Gaboury L, Oligny L and Desjardins JG. Prophylactic thyroidectomy for medullary thyroid carcinoma in gene carriers of MEN2 syndrome. J Pediatr Surg 1998; 33: 846-848

47. Arts CH, Bax NM, Jansen M, Lips CJ, Vroom TM and van Vroonhoven TJ. Prophylactic total thyroidectomy in childhood for multiple endocrine neoplasia type 2A: preliminary results. Ned Tijdschr Geneeskd 1999; 143: 98-104.

48. van Heurn LW, Schaap C, Sie G, Haagen AA, Gerver WJ, Freling $G$, van Amstel HK and Heineman E. Predictive DNA testing for multiple endocrine neoplasia 2: a therapeutic challenge of prophylactic thyroidectomy in very young children. J Pediatr Surg 1999; 34: 568-571.

49. Iler MA, King DR, Ginn-Pease ME, O'Dorisio TM and Sotos JF. Multiple endocrine neoplasia type 2A: a 25-year review. J Pediatr Surg 1999; 34: 92-96.

50. Niccoli-Sire P, Murat A, Baudin E, Henry JF, Proye C, Bigorgne JC, Bstandig B, Modigliani E, Morange S, Schlumberger M and Conte-Devolx B. Early or prophylactic thyroidectomy in MEN 2/FMTC gene carriers: results in 71 thyroidectomized patients. The French Calcitonin Tumours Study Group (GETC). Eur J Endocrinol 1999; 141: 468-474

51. Ukkat J, Lorenz K, Hinze R, Thomusch $\bigcirc$ and Dralle $H$. Importance of early screening and prophylactic thyroidectomy in asymptomatic nonindex RET germline carriers. World J Surg $2001 ; 25: 713-717$

52. Sanso GE, Domene HM, Garcia R, Pusiol E, de M, Roque M, Ring $A$, Perinetti $H$, Elsner B, lorcansky $S$ and Barontini M. Very early detection of RET proto-oncogene mutation is crucial for preventive thyroidectomy in multiple endocrine neoplasia type 2 children: presence of $\mathrm{C}$-cell malignant disease in asymptomatic carriers. Cancer 2002; 94: 323-330.

53. Rodriguez GJ, Balsalobre MD, Pomares F, Torregrosa NM, Rios A, Carbonell P, Glower G, Sola J, Tebar J and Parrilla P. Prophylactic thyroidectomy in MEN 2A syndrome: experience in a single center. J Am Coll Surg 2002; 195: 159-166.

54. Brauckhoff M, Gimm O, Weiss CL, Ukkat J, Sekulla C, Brauckhoff K, Thanh PN and Dralle H. Multiple endocrine neoplasia 2B syndrome due to codon 918 mutation: clinical manifestation and course in early and late onset disease. World J Surg 2004; 28: 1305-1311.

55. Kahraman T, de Groot JW, Rouwe C, Hofstra RM, Links TP, Sijmons RH and Plukker JT. Acceptable age for prophylactic surgery in children with multiple endocrine neoplasia type 2 a. Eur J Surg Oncol 2003; 29: 331-335.

56. de Groot JW, Links TP, Rouwe CW, van der Wal JE, Hofstra RM and Plukker JT. Prophylactic thyroidectomy in children who are carriers of a multiple endocrine neoplasia type 2 mutation: description of 20 cases and recommendations based on the literature. Ned Tijdschr Geneeskd 2006; 150: 311 -318.

57. Sosa JA, Bowman HM, Tielsch JM, Powe NR, Gordon TA and Udelsman R. The importance of surgeon experience for clinical and economic outcomes from thyroidectomy. Ann Surg 1998; 228: $320-330$.

58. Modigliani E, Cohen R, Campos JM, Conte-Devolx B, Maes B, Boneu A, Schlumberger M, Bigorgne JC, Dumontier P, Leclerc L, Corcuff B and Guilhem I. Prognostic factors for survival and for biochemical cure in medullary thyroid carcinoma: results in 899 patients. The GETC Study Group. Groupe d'etude des tumeurs a calcitonine. Clin Endocrinol (Oxf) 1998; 48: 265 273.

59. Hyer SL, Vini L, A'Hern R and Harmer C. Medullary thyroid cancer: multivariate analysis of prognostic factors influencing survival. Eur J Surg Oncol 2000; 26: 686-690.

60. de Groot JW, Plukker JT, Wolffenbuttel BH, Wiggers T, Sluiter WJ and Links TP. Determinants of life expectancy in medullary thyroid cancer: Age does not matter. Clin Endocrinol (Oxf) 2006 (in press).

61. de Groot JW, Links TP, Jager PL, Kahraman T and Plukker JT. Impact of 18F-fluoro-2-deoxy-D-glucose positron emission tomography (FDG-PET) in patients with biochemical evidence of recurrent or residual medullary thyroid cancer. Ann Surg Oncol 2004; 11: 786-794. 